\title{
Non-lupus full-house nephropathy-immune dysregulation as a rare cause of pediatric nephrotic syndrome: Answers
}

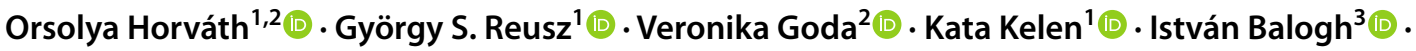

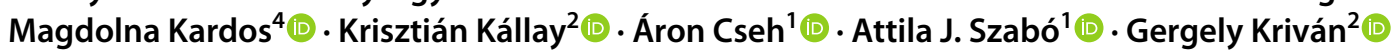

Received: 6 November 2021 / Accepted: 8 November 2021 / Published online: 17 December 2021

(c) The Author(s) 2021, corrected publication 2022

Keywords "Full-house" nephropathy (FHN) · Autoimmunity · Primary immunodeficiency (PID) · IPEX syndrome · FOXP3 mutation

\section{What is the most likely diagnosis?}

Based on the synchroneity of severe infections, multiple autoimmune disorders, atopic dermatitis, chronic diarrhoea and insufficient weight gain, the "immunodysregulation, polyendocrinopathy, enteropathy, X-linked" (IPEX) or IPEXlike syndrome was first suspected at the age of 8 in 2015, and calcineurin inhibitor tacrolimus was introduced [1].

IPEX syndrome is a rare primary immunodeficiency syndrome characterized by the development of multiple autoimmune disorders. IPEX is caused by mutations in the forkhead box protein 3 gene (FOXP3), which encodes a key transcription factor required for regulatory $\mathrm{T}$ cell (Treg) development, maintenance and function [2]. In addition to the traditional clinical presentation (severe enteropathy, type 1 diabetes and skin lesions), IPEX may include other variable and distinct clinical manifestations [3]. The coding region of FOXP3 was analysed by Sanger sequencing and a silent mutation was detected $(\mathrm{c} .816 \mathrm{G}>\mathrm{A})$. To assess the potential effect of the

This refers to the article that can be found at http://dx.doi.org/10. 1007/s00467-021-05359-3

György S. Reusz

reusz.gyorgy@med.semmelweis-univ.hu

1 1St Department of Pediatrics, Semmelweis University, 53-54 Bókay János Street, Budapest 1083, Hungary

2 Pediatric Hematology and Stem Cell Transplantation Unit, Central Hospital of Southern Pest, National Institute of Hematology and Infectious Diseases, Budapest, Hungary

3 Department of Laboratory Medicine, Division of Clinical Genetics, Department of Human Genetics, Faculty of Medicine, University of Debrecen, Debrecen, Hungary

4 2Nd Department of Pathology, Semmelweis University, Budapest, Hungary mutation on RNA splicing, RNA of peripheral white blood cells was tested and the skipping of exon 7 was observed; thus, the effect of the mutation was p.Leu246fs*160 [4].

Treg cell dysfunction is the main pathogenic event leading to multiorgan autoimmunity in IPEX [3]. Functional data demonstrate that Treg cells isolated from IPEX patients are dysfunctional, as they cannot inhibit proliferation and cytokine production of autologous or allogenic $\mathrm{T}$ effector cells [3].

Our patient had typical (enteropathy, skin lesions, severe infections) and atypical (non-lupus full-house nephropathy) symptoms without type 1 diabetes leading to the diagnosis of IPEX. Treg cell count was at the lower limit of normal range $(\mathrm{CD} 3+/ \mathrm{CD} 4+\mathrm{T}$ cell count $503 \mathrm{cell} / \mu \mathrm{L}$ (lower limit of normal 300 cell $/ \mu \mathrm{L}), 4.6 \%$ Treg cells of the CD3+/ CD4 + cells (normal range 4-9\%)). Treg cell subpopulations and intracellular cytokine production were not evaluated and functional $\mathrm{T}$ cell tests were not available at the time of diagnosis.

\section{What is the possible underlying mechanism of kidney involvement?}

Non-lupus full-house nephropathy (FHN) was the most remarkable and rare symptom of the multiple autoimmune disorder. FHN is a rare kidney disease characterized by a variety of glomerular lesions typically accompanied by extensive deposition of all classes of immunoglobulins and complement components along different sites of the glomerulus [5]. Different forms of kidney injury have been reported in IPEX syndrome, such as membranous nephropathy and minimal change nephrotic syndrome [6-8]. B cells in IPEX show altered antibody production, and tissue-specific 
autoantibodies can be detected early [9]. Anti-villin and harmonin autoantibodies are highly expressed in proximal tubules, which can also explain the wide range of kidney involvement in IPEX syndrome [9]. Furthermore, in our patient's case, it is not clear whether non-lupus FHN was part of the clinical spectrum as a result of immune dysregulation, or was secondary to medications, infections or other concomitant insults. In this case, non-lupus FHN was treated as lupus nephritis and went into remission after the third cyclophosphamide pulse and remained in remission during azathioprine and later tacrolimus treatment. Similar to our results, high complete response rate was found in pediatric patients with non-lupus FHN [10].

\section{What is the treatment and the prognosis of the disease?}

Currently, the therapeutic approach to IPEX syndrome is not standardized; patient management is based on single-centre experiences. Immunosuppressive treatment (IST) is the treatment of choice; however, its role in controlling dysfunctional Treg cells is not clear [1]. Disease manifestations improve in half of the cases treated with IST alone [11]. Based on clinical signs and the results of flow cytometry, our patient was treated for IPEX-like syndrome after 2015 (Fig. 1). IST with steroids, cyclophosphamide, azathioprine and finally tacrolimus
Fig. 1 a Patient flow chart for the Questions part. NS indicates nephrotic syndrome. b Patient flow chart for the Answers part. HSCT indicates hematopoietic stem cell transplantation; IPEX, immunodysregulation, polyendocrinopathy, enteropathy, $\mathrm{X}$-linked (IPEX) syndrome; NS, nephrotic syndrome. Tacrolimus was started as immunosuppressive therapy after the suspicion for IPEX syndrome and continued as graft-versus-host disease prophylaxis for 110 days after HSCT a

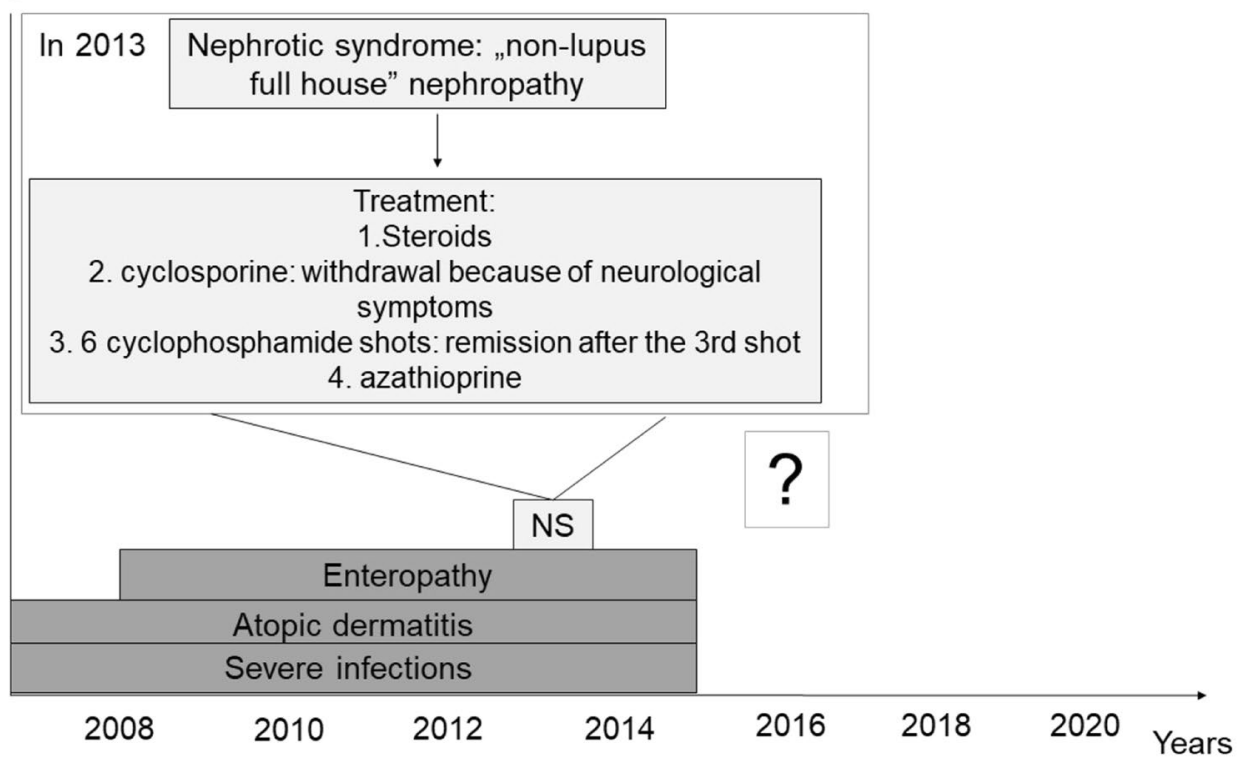

b

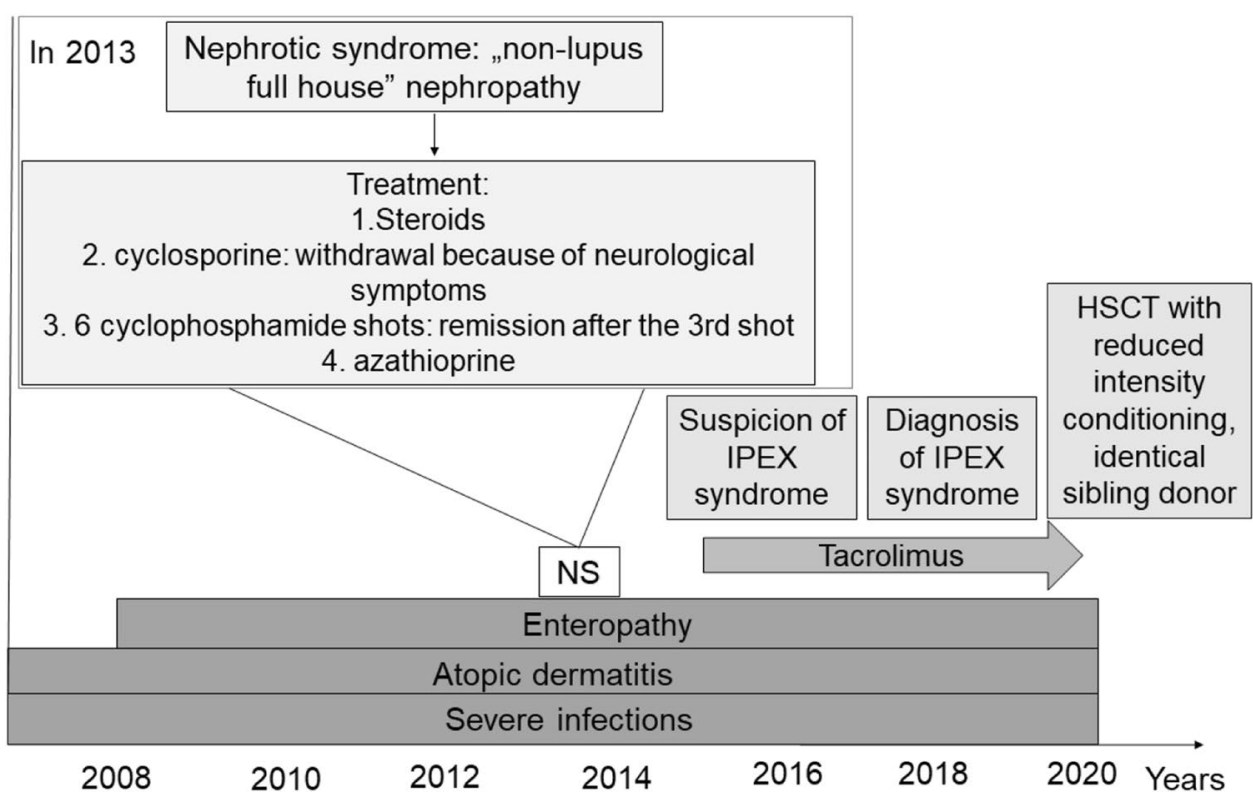


resulted in only partial control of the disease. The main reason for hematopoietic stem cell transplantation (HSCT) was uncontrolled autoimmune enteropathy, failure to thrive (body mass index (BMI) z-score -1.5), persisting skin symptoms and poor quality of life. HSCT is currently the only curative therapy for IPEX syndrome and can result in favourable outcome with improved quality of life $[1,11,12]$. In the present case, considering the non-malignant indication, reduced intensity HSCT conditioning regimen was used. Treatment-related toxicity was well tolerated and oral nutrition could be started. HSCT was performed with an identical female sibling donor and tacrolimus as graft-versus-host disease prophylaxis could be discontinued early, 4 months after HSCT.

\section{Patient outcome}

One year after HSCT, at the age of 14, the patient lives without IST, has normal kidney function and blood pressure, no haematuria and proteinuria below $15 \mathrm{mg} / \mathrm{m}^{2} / \mathrm{h}$. The patient tolerates normal enteral nutrition well, and moreover gained weight and height (BMI z-score 0.03) as well.

\section{Conclusion}

In conclusion, severe immune dysregulation in IPEX syndrome can be an underlying cause in the pathomechanism of non-lupus full-house nephropathy, a rare cause of nephrotic syndrome in childhood. With combined IST, long-term remission of NS was achieved, HSCT was necessary to control the severe extrarenal clinical symptoms. In such cases of FHN, patients should be screened for primary immunodeficiency.

Funding Open access funding provided by Semmelweis University. The study was supported by the Hungarian National Research, Development, and Innovation Office grant NKFI-124549 (RGS).

Availability of data and material Not applicable.

Code availability Not applicable.

\section{Declarations}

Conflict of interest The authors declare no competing interests.

Open Access This article is licensed under a Creative Commons Attribution 4.0 International License, which permits use, sharing, adaptation, distribution and reproduction in any medium or format, as long as you give appropriate credit to the original author(s) and the source, provide a link to the Creative Commons licence, and indicate if changes were made. The images or other third party material in this article are included in the article's Creative Commons licence, unless indicated otherwise in a credit line to the material. If material is not included in the article's Creative Commons licence and your intended use is not permitted by statutory regulation or exceeds the permitted use, you will need to obtain permission directly from the copyright holder. To view a copy of this licence, visit http://creativecommons.org/licenses/by/4.0/.

\section{References}

1. Ben-Skowronek I (2021) IPEX syndrome: genetics and treatment options. Genes 12:323. https://doi.org/10.3390/genes12030323

2. Katoh H, Zheng P, Liu Y (2013) FOXP3: genetic and epigenetic implications for autoimmunity. J Autoimmun 41:72-78. https:// doi.org/10.1016/j.jaut.2012.12.004

3. Bacchetta R, Barzaghi F, Roncarolo MG (2016) From IPEX syndrome to FOXP3 mutation: a lesson on immune dysregulation. Ann N Y Acad Sci 1417:5-22. https://doi.org/10.1111/nyas.13011

4. Magg T, Mannert J, Ellwart JW, Schmid I, Albert MH (2012) Subcellular localization of FOXP3 in human regulatory and nonregulatory T cells. Eur J Immunol 42:1627-1638. https://doi.org/ 10.1002/eji.201141838

5. Gianviti A, Barsotti P, Barbera V, Faraggiana T, Rizzoni G (1999) Delayed onset of systemic lupus erythematosus in patients with "full-house" nephropathy. Pediatr Nephrol 13:683-687. https:// doi.org/10.1007/s004670050681

6. Chuva T, Pfister F, Beringer O, Felgentreff K, Büttner-Herold M, Amann K (2017) PLA2R-positive (primary) membranous nephropathy in a child with IPEX syndrome. Pediatr Nephrol 32:1621-1624. https://doi.org/10.1007/s00467-017-3682-8

7. Hashimura Y, Nozu K, Kanegane H, Miyawaki T, Hayakawa A, Yoshikawa N, Nakanishi K, Takemoto M, Iijima K, Matsuo M (2009) Minimal change nephrotic syndrome associated with immune dysregulation, polyendocrinopathy, enteropathy, X-linked syndrome. Pediatr Nephrol 24:1181-1186. https://doi.org/10. 1007/s00467-009-1119-8

8. Moudgil A, Perriello P, Loechelt B, Przygodzki R, Fitzerald W, Kamani N (2007) Immunodysregulation, polyendocrinopathy, enteropathy, X-linked (IPEX) syndrome: an unusual cause of proteinuria in infancy. Pediatr Nephrol 22:1799-1802. https://doi.org/ 10.1007/s00467-007-0532-0

9. Tsuji S, Kimata T, Yamanouchi S, Kitao T, Kino J, Suruda C, Kaneko K (2017) Regulatory T cells and CTLA-4 in idiopathic nephrotic syndrome. Pediatr Int 59:643-646. https://doi.org/10. 1111/ped.13255

10. Ruggiero B, Vivarelli M, Gianviti A, Pecoraro C, Peruzzi L, Benetti E, Ventura G, Pennesi M, Murer L, Coppo R, Emma F (2017) Outcome of childhood-onset full-house nephropathy. Nephrol Dial Transplant 32:1194-1204. https://doi.org/10.1093/ndt/gfw230

11. Barzaghi F, Amaya Hernandez LC, Neven B, Ricci S, Kucuk ZY, Bleesing JJ, Nademi Z, Slatter MA, Ulloa ER, Shcherbina A, Roppelt A, Worth A, Silva J, Aiuti A, Murguia-Favela L, Speckmann C, Carneiro-Sampaio M, Fernandes JF, Baris S, Ozen A, KarakocAydiner E, Kiykim A, Schulz A, Steinmann S, Notarangelo LD, Gambineri E, Lionetti P, Shearer WT, Forbes LR, Martinez C, Moshous D, Blanche S, Fisher A, Ruemmele FM, Tissandier C, Ouachee-Chardin M, Rieux-Laucat F, Cavazzana M, Qasim W, Lucarelli B, Albert MH, Kobayashi I, Alonso L, Diaz De Heredia C, Kanegane H, Lawitschka A, Seo JJ, Gonzalez-Vicent M, Diaz MA, Goyal RK, Sauer MG, Yesilipek A, Kim M, YilmazDemirdag Y, Bhatia M, Khlevner J, Richmond Padilla EJ, Martino S, Montin D, Neth O, Molinos-Quintana A, Valverde-Fernandez J, Broides A, Pinsk V, Ballauf A, Haerynck F, Bordon V, Dhooge C, Garcia-Lloret ML, Bredius RG, Kałwak K, Haddad E, Seidel MG, Duckers G, Pai SY, Dvorak CC, Ehl S, Locatelli F, Goldman F, Gennery AR, Cowan MJ, Roncarolo MG, Bacchetta R, 
Primary Immune Deficiency Treatment Consortium (PIDTC) and the Inborn Errors Working Party (IEWP) of the European Society for Blood and Marrow Transplantation (EBMT) (2018) Long-term follow-up of IPEX syndrome patients after different therapeutic strategies: an international multicenter retrospective study. J Allergy Clin Immunol 141:1036-1049.e5. https://doi.org/ 10.1016/j.jaci.2017.10.041

12. Jamee M, Zaki-Dizaji M, Lo B, Abolhassani H, Aghamahdi F, Mosavian M, Nademi Z, Mohammadi H, Jadidi-Niaragh F, Rojas M, Anaya JM, Azizi G (2020) Clinical, immunological, and genetic features in patients with immune dysregulation, polyendocrinopathy, enteropathy, X-linked (IPEX) and IPEX-like syndrome. J Allergy Clin Immunol Pract 8:2747-2760.e7. https://doi. org/10.1016/j.jaip.2020.04.070

Publisher's note Springer Nature remains neutral with regard to jurisdictional claims in published maps and institutional affiliations. 